\title{
Risk of colonoscopic post-polypectomy bleeding in patients on single antiplatelet therapy: systematic review with meta-analysis
}

\author{
Marco Valvano $^{1}$ - Stefano Fabiani ${ }^{1} \cdot$ Marco Magistroni ${ }^{1}$. Antonio Mancusi ${ }^{1}$ - Salvatore Longo ${ }^{1}$. \\ Gianpiero Stefanelli ${ }^{1} \cdot$ Filippo Vernia $^{1} \cdot$ Angelo Viscido $^{1} \cdot$ Silvio Romano $^{2} \cdot$ Giovanni Latella $^{1}$ (i)
}

Received: 29 July 2021 / Accepted: 31 December 2021 / Published online: 13 January 2022

(c) The Author(s) 2022

\begin{abstract}
Background It was not yet fully established whether the use of antiplatelet agents (APAs) is associated with an increased risk of colorectal post-polypectomy bleeding (PPB). Temporarily, discontinuation of APAs could reduce the risk of PPB, but at the same time, it could increase the risk of cardiovascular disease recurrence. This study aimed to assess the PPB risk in patients using APAs compared to patients without APAs or anticoagulant therapy who had undergone colonoscopy with polypectomy.

Methods A systematic electronic search of the literature was performed using PubMed/MEDLINE, Scopus, and CENTRAL, to assess the risk of bleeding in patients who do not interrupt single antiplatelet therapy (P2Y12 inhibitors or aspirin) and undergone colonoscopy with polypectomy.

Results Of 2417 identified articles, 8 articles (all of them were non-randomized studies of interventions (NRSI); no randomized controlled trials (RCT) were available on this topic) were selected for the meta-analysis, including 1620 patients on antiplatelet therapy and 13,321 controls. Uninterrupted APAs single therapy was associated with an increased risk of PPB compared to the control group (OR 2.31; CI 1.37-3.91). Patients on P2Y12i single therapy had a higher risk of both immediate (OR 4.43; CI 1.40-14.00) and delayed PPB (OR 10.80; CI 4.63-25.16) compared to the control group, while patients on aspirin single therapy may have a little to no difference increase in the number of both immediate and delayed PPB events. Conclusions Uninterrupted single antiplatelet therapy may increase the risk of PPB, but the evidence is very uncertain. The risk may be higher in delayed PPB. However, in deciding to discontinue APAs before colonoscopy with polypectomy, the potential higher risk of major adverse cardiovascular events should always be assessed.
\end{abstract}

Keywords Aspirin · Platelet aggregation inhibitors $\cdot$ Antiplatelet agents $\cdot$ Haemorrhage $\cdot$ Intestinal polyps $\cdot$ Colonoscopy Polypectomy $\cdot$ Post-polypectomy bleeding

Endoscopic techniques are becoming increasingly popular for both diagnostic and interventional procedures for gastrointestinal diseases. Given the high volume of these procedures, it is increasingly necessary to perform the endoscopic exam in a condition of safety for patients [1].

Giovanni Latella giolatel@tin.it

1 Gastroenterology Unit, Department of Life, Health and Environmental Sciences, University of L'Aquila, Piazzale Salvatore Tommasi 1, 67100 L'Aquila, Italy

2 Cardiology Unit, Department of Life, Health and Environmental Sciences, University of L'Aquila, L'Aquila, Italy
A meta-analysis including 14 studies, estimated that the overall pooled prevalence for mortality, perforation, and post-colonoscopy bleeding were $2.9 / 100,000$ (95\% confidence interval (CI) 1.1-5.5), 0.5/1,000 (95\% CI 0.4-0.7), and 2.6/1000 (95\% CI 1.7-3.7), respectively. This risk was higher in patients undergoing colonoscopic polypectomy, with a post-polypectomy bleeding (PPB) rate of 9.8 per 1000 polypectomies (95\% CI 7.7-12.1) [2].

Furthermore, polypectomy is considered a high risk of bleeding procedure in particular in elderly patients $[3,4]$. An observational study reported that age $>75$ was independently associated with an increase of emergency department visit (OR 1.58; 95\% CI 1.05-2.37) and hospitalization (OR 3.7; 95\% CI 2.03-6.73) within 7 days of colonoscopy [5]. Taking into account the high mean age 
of patients who underwent an endoscopic procedure, it is common to find patients with many comorbidities [6] such as cardiovascular disease in antithrombotic treatment. It is estimated that $44.6 \%$ of over $70 \mathrm{~s}$ use aspirin among the U.S. population [7].

Antithrombotic therapy is used to reduce the risk of thrombotic/thromboembolic events in patients with several conditions such as atrial fibrillation (AF) and coronary artery disease (CAD); however, these drugs are linked to an increased risk of bleeding $[8,9]$. Antithrombotic include anticoagulants or antiplatelet agents (APAs). The latter include aspirin and P2Y12 inhibitors (P2Y12i), such as clopidogrel, prasugrel, and ticagrelor which are commonly used to prevent thrombosis in patients who have had coronary stents, recent myocardial infarctions, peripheral stents for vascular disease, and cerebrovascular disease.

Many guidelines already exist on the management of APAs for the patient undergoing gastrointestinal endoscopy; Regarding the high-risk procedures, American guidelines (ASGE) suggest interrupting P2Y12i five days before the procedure in patients with low cardiovascular risk. Moreover, P2Y12i should be continued in patients at high risk of cardiovascular disease. The aspirin should never be interrupted [4]. While European (ESGE) guidelines suggest, in high-risk procedures, interrupting P2Y12i seven days before the procedure in patients with low cardiovascular risk; in patients with high cardiovascular risk is suggested to discuss strategy with a consultant interventional cardiologist. Patients on dual antiplatelet therapy should never interrupt the aspirin and consider temporary cessation of $\mathrm{P} 2 \mathrm{Y} 12 \mathrm{i}$ 6-12 months after drug-eluting stent insertion, or at least 1 month after bare metal stent insertion. However, the quality of this evidence ranges from moderate to low $[3,4]$.

For all these reasons, it is important to balance the postpolypectomy risk of bleeding and the risk of cardiovascular disease recurrence for the proper management of the suspensions APAs [10].

In particular, taking aspirin the risk of bleeding in a patient undergoing colonoscopy with polypectomy (with forceps, cold or hot snare) seems only slightly increased [3]; on the other hand, aspirin non-adherence or withdrawal is associated with a three-fold higher risk of major adverse cardiovascular events (OR 3.14; CI 1.75-5.61) [11]. Therefore, it seems reasonable to continue single antiplatelet therapy in patients undergoing colonoscopic polypectomy, in particular in patients with a high risk of cardiovascular disease [3]. To support this clinical evidence, it is necessary to assess PPB risk in patients on uninterrupted single antiplatelet therapy before colonoscopy with polypectomy.

We performed a systematic review with meta-analysis to assess the risk of bleeding in patients who did not interrupt single antiplatelet therapy (P2Y12i or aspirin) before colonoscopy with polypectomy.

\section{Materials and methods}

\section{Study protocol}

We reported a systematic review and meta-analysis according to the PRISMA guidelines [12] (Supplementary Table 1) using a predetermined protocol (PROSPERO $\mathrm{n}$ : CRD42020214769; October 2020).

A systematic electronic search for relevant publications (without language or date of publication restrictions) was performed by three investigators. The search included a combination of Medical Subject Headings (MeSH) and keywords (Supplementary Table 2).

Studies were identified using the following database: PubMed/MEDLINE, Scopus, and CENTRAL. Each of the relevant publication reference sections, and Google Scholar were also screened for other applicable publications. ClinicalTrial.gov was investigated to find unpublished completed trials.

Relevant abstracts were also screened. The last search was performed in January 2021.

We considered both randomized controlled trial and non-randomized studies (prospective and retrospective cohort studies, case-control studies, and analytical crosssectional studies).

\section{Outcome of interest}

The primary outcome of our meta-analysis was to assess the incidence of both immediate and delayed PPB in patients on APAs therapy undergoing colonoscopic polypectomy (expressed as dichotomous outcomes). We performed a subgroup analysis when it was possible, including:

- Risk of PPB (both immediate and delayed) in the P2Y12i group vs control.

- Risk of PPB (both immediate and delayed) in the aspirin group vs control.

Sensitivity analysis after the exclusion of studies not published as full-text and the studies with serious risk of bias assessed by ROBINS-I tool was performed [13].

The evidence produced in this meta-analysis was graded and presented according to the Grading of Recommendations Assessment, Development, and Evaluation (GRADE) system [14-16].

\section{Immediate post-polypectomy bleeding}

Bleeding after polypectomy occurring at the time of colonoscopy or before discharge from the Endoscopy Unit. 


\section{Delayed post-polypectomy bleeding}

Rectal bleeding occurred the day after within 30 days after polypectomy.

\section{Selection of studies}

Three authors (MV, AM, and SF) independently reviewed abstracts and manuscripts for eligibility. Conflicts were resolved by consensus, referring to the original articles. Studies were selected with the following criteria:

\section{Inclusion criteria}

1. Both randomized controlled trials (RCTs) and non-randomized studies of interventions (NRSI) with prospective or retrospective designs without language or date of publication restrictions.

2. Studies including patients on antiplatelet therapy (both P2Y12i and aspirin) undergoing colonoscopy with polypectomy.

3. Studies including a control group of patients without or discontinuing antithrombotic therapy.

4. Studies evaluating immediate PPB or complications after polypectomy.

5. Studies evaluating delayed PPB or complications after polypectomy.

6. Presented Odds ratio (OR), relative risk (RR), Hazard ratio (HR), or the number of events necessary to calculate these for the outcome of the interest rate.

7. When multiple publications from the same study or institution were available, the most recent publication has been used.

\section{Exclusion criteria}

1. Studies evaluating PPB or complications without an intervention group on APAs therapy (both P2Y12i and aspirin).

2. Studies evaluating PPB or complications with a control group with patients on antithrombotic therapy who were non-excludable.

3. Patients on dual antiplatelet therapy (DAPT) who were non-excludable from the intervention group.

4. Concomitant use of anticoagulant therapy (warfarin, direct oral anticoagulation, or heparin).

5. Patients underwent Endoscopic Mucosal Resection (EMR) or Endoscopic Sub-mucosal Dissection (ESD) who were non-excludable from both the intervention and control group.

\section{Data extraction and assessment of the risk of bias}

Two reviewers (AM and SF) independently extracted the following data variables: title and reference details (first author, journal, year, country), study population characteristics (number of patients included in the study, gender and age, antiplatelet therapy, dosage, setting), outcome data (PPB, complication after polypectomy or death), polyp size and polypectomy technique.

All data were recorded independently by both literature reviewers in separate databases and were compared at the end of the reviewing process to limit selection bias. The database was then reviewed by a third person (MM) and any disparities were discussed and clarified with the consultation of the senior co-authors (AV and GL). Any conflicts were resolved by consensus, referring to the original articles.

The Authors of the eligible studies were contacted for additional information in the occurrence of the inconsistency of reported results during data extraction.

Two authors (MM and SF) independently assessed the risk of bias of included studies using the ROBINS-I tool [13]. Significant conflicts were resolved by consensus, reevaluating the original articles, and if necessary, with the consultation of the senior co-authors (AV and GL).

Are considered as possible confounding domains relevant to all or most studies: polypectomy technique, polyps size, number of polyps per patient, location, morphology, histology, age, and comorbidities.

\section{Statistical analyses}

Dichotomous outcomes were expressed as the OR with a 95\% confidence interval (CI). The Odds Ratio for the individual study was combined using a random-effect model, with a fixed-effects model planned for non-significant heterogeneity $\left(\mathrm{p}>0.10, \mathrm{I}^{2}<50 \%\right)$. The Mantel-Haenszel method was used to perform meta-analyses with the Review Manager software (Version 5.3. Copenhagen, Denmark: The Nordic Cochrane Centre, The Cochrane Collaboration, 2014). Heterogeneity was calculated using the $\chi^{2}$ test and $\mathrm{I}^{2}$ statistic defined by the Cochrane Handbook for Systematic Reviews [17].

We planned to examine publication bias using funnel plots for outcomes if data from 10 or more studies were available.

In this case, Egger's regression test will be also performed for our primary analysis to assess for potential publication bias using the STATA/IC software Version v16.1 (2017, College Station, TX) [18].

Results will be considered statistically significant at the $\mathrm{p}<0.05$ level (if the $95 \%$ does not include the value of 1 ). 


\section{Summary of findings and GRADE profile}

We will present the main findings of the review concerning the certainty of the evidence, and magnitude of the effect of the interventions examined, in "Summary of findings" table, according to the GRADE [17, 19].

\section{Results}

Figure 1 shows the PRISMA flow diagram, including results of the literature search, as assessed by the three authors (MV, AM, and SF). We found 2417 articles, removing 186 duplicated records, excluding 2195 records based on their titles and abstracts. Among the 37 full texts assessed for eligibility, we included 8 articles (7 full-text and 1 abstract) for the quantitative synthesis, including 1,620 patients on antiplatelet therapy (P2Y12i or Aspirin) and 13,321 controls [20-27]. The characteristics of the eight selected studies are reported in Table 1 and in Supplementary Table 3. Definitions of clinical outcome measures set by individual studies are summarized in Table 2.

Six studies used a retrospective design [20-22, 25-27], while two used a prospective design [23, 24]. Six studies included both aspirin and P2Y12i users. Among these studies, five were separately analysed in a subgroup analysis to establish the PPB risk for each group [21, 23-25, 27].

One study included in our meta-analysis was a cohort study including only patients with significant PPB and a matched control group without complication at colonoscopy. As result, the incidence of PPB bleeding was higher than the other studies (54.2\% vs $47.6 \%$ in APAs and control group, respectively) [20].

Three studies assessed the PPB rate in patients who underwent colonoscopic polypectomy with hot snare [27], cold snare [25], or both [26].

Uninterrupted APAs single therapy was associated with an increased risk of PPB compared to control group $(5.4 \%$ vs $1.8 \%$ ).

The risk of bias of the included studies assessed by the ROBINS-I is summarized in Supplementary Table 4; 7 studies had moderate risk of bias and 1 had serious risk.

Table 3 showed the main results of the review concerning the certainty of the evidence and magnitude of the effect of the interventions examined.

\section{Description of excluded studies}

The reasons for the exclusion of 29 studies that were not included in this review are summarized in Supplementary Table 5. Among these studies, 2 did not evaluate PPB; 3 did

Fig. 1 PRISMA flow diagram
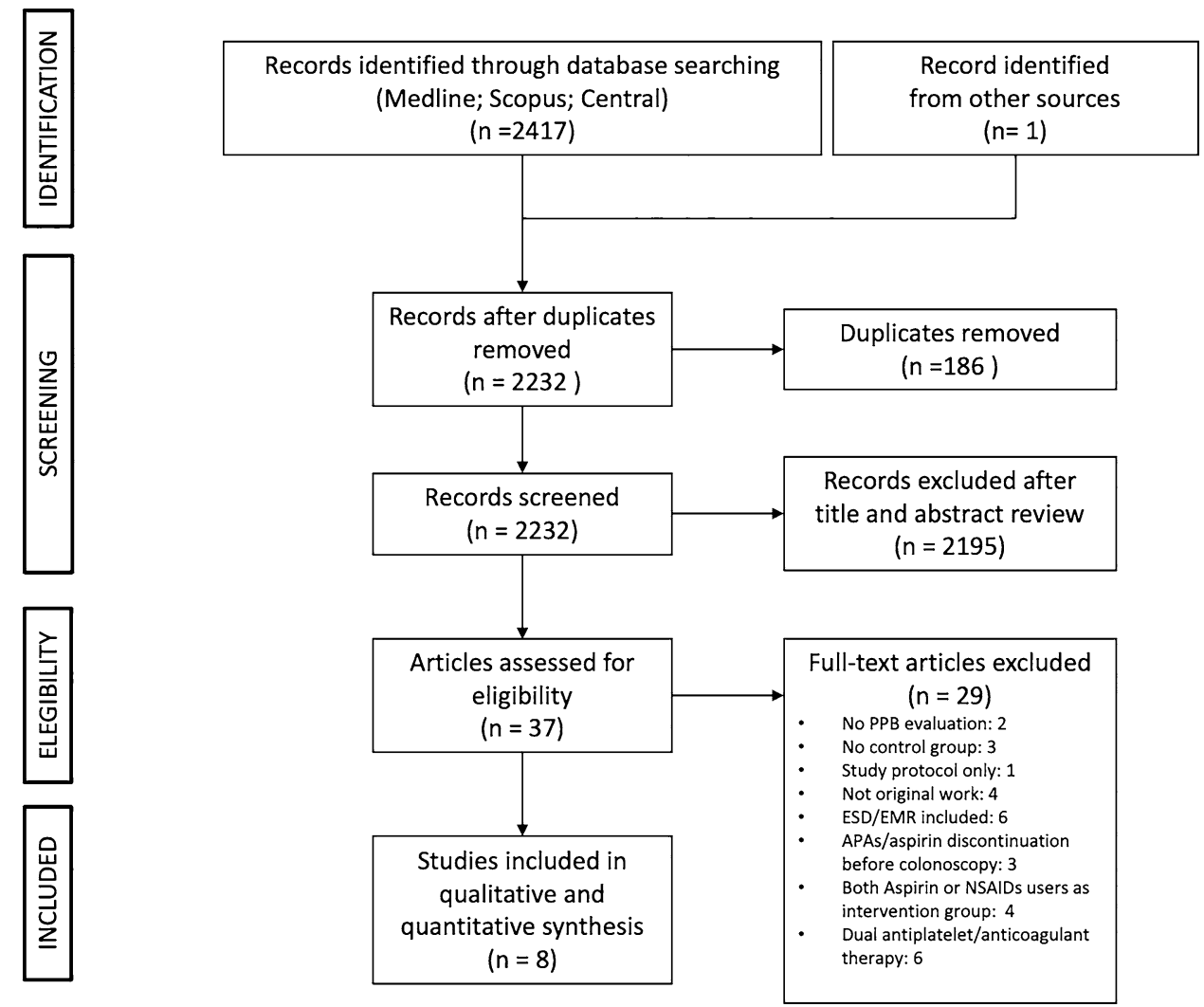
Table 1 Baseline characteristics of included studies

\begin{tabular}{|c|c|c|c|c|c|c|c|}
\hline Study & Pop & Male $\%$ & $\operatorname{Age}^{a, b}$ & Design & Setting & $\begin{array}{l}\text { Uninterrupted anti- } \\
\text { platelet agents }\end{array}$ & $\begin{array}{l}\text { Definition of control } \\
\text { group }\end{array}$ \\
\hline $\begin{array}{l}\text { Amato } 2016 \\
\text { (Italy) }\end{array}$ & 2692 & $54.3 \%$ & $\begin{array}{l}59 \\
( \pm 12.1)^{\mathrm{a}}\end{array}$ & NRSI (Prospective) & $\begin{array}{l}\text { Multicentric; CRC } \\
\text { screening }\end{array}$ & APAs & $\begin{array}{l}\text { No treatment or APAs } \\
\text { suspension for at } \\
\text { least five days }\end{array}$ \\
\hline $\begin{array}{l}\text { Feagins } 2013 \\
\text { (USA) }\end{array}$ & 516 & $97 \%$ & $62.4^{\mathrm{a}}$ & NRSI (Prospective) & VA hospital & APAs & No treatment \\
\hline $\begin{array}{l}\text { Grossman } 2010 \\
\text { (USA) }\end{array}$ & 3191 & n.a & n.a & NRSI (Retrospective) & Endoscopic unit & Clopidogrel & No treatment \\
\hline $\begin{array}{l}\text { Hui } 2004 \\
\text { (China) }\end{array}$ & 1657 & $55.9 \%$ & $\begin{array}{l}64.4 \\
( \pm 13)^{\mathrm{a}}\end{array}$ & NRSI (Retrospective) & Endoscopic unit & $\begin{array}{l}\text { Aspirin and Clopi- } \\
\text { dogrel }\end{array}$ & No treatment \\
\hline $\begin{array}{l}\text { Kishida } 2018 \\
\text { (Japan) }\end{array}$ & 6382 & $70.6 \%$ & $\begin{array}{l}68 \\
(17-96)^{b}\end{array}$ & NRSI (Retrospective) & Endoscopic unit & APAs & $\begin{array}{l}\text { No treatment or } \\
\text { antithrombotic sus- } \\
\text { pension according to } \\
\text { the JGES guidelines }\end{array}$ \\
\hline $\begin{array}{l}\text { Matsumoto } 2018 \\
\text { (Japan) }\end{array}$ & 1003 & $69.7 \%$ & n.a & NRSI (Retrospective) & Endoscopic unit & APAs & No treatment \\
\hline $\begin{array}{l}\text { Watanabe } 2020 \\
\text { (Japan) }\end{array}$ & 1050 & $72.1 \%$ & n.a & NRSI (Retrospective) & Endoscopic unit & APAs & No treatment \\
\hline $\begin{array}{l}\text { Yousfi } 2004 \\
\text { (USA) }\end{array}$ & 162 & $61.7 \%$ & $\begin{array}{l}72 \\
(45-91)^{b}\end{array}$ & NRSI (Retrospective) & $\begin{array}{l}\text { Multicentric; Endo- } \\
\text { scopic unit }\end{array}$ & Aspirin & No treatment \\
\hline
\end{tabular}

NRSI non-randomized study of intervention, APAs antiplatelet agents (both P2Y12i and aspirin), CRC colorectal cancer, VA veteran affairs, JGES Japan Gastroenterological Endoscopy Society

${ }^{\mathrm{a}}$ Mean $( \pm \mathrm{SD})$

${ }^{\mathrm{b}}$ Median (range)

not include a control group without antithrombotic therapy; 1 was a study protocol; 4 were not original works; 6 included patients undergoing both ESD and EMR; 3 discontinued P2Y12i or aspirin before the colonoscopy; 4 included both aspirin or NSAIDs users as intervention group; 6 included patients on DAPT or anticoagulant therapy.

\section{Overall immediate and delayed post-polypectomy bleeding}

Eight studies assessed the PPB risk in patients on single antiplatelet therapy (P2Y12i or aspirin) [20-27]. Out of 1620 patients on single APAs therapy, 181 patients were on uninterrupted P2Y12i single therapy, 751 were on uninterrupted aspirin single therapy, 688 were on uninterrupted APAs single therapy (which APAs was not specified).

Uninterrupted APAs single therapy was associated with an increased risk of PPB compared to control group (OR 2.31; CI 1.37-3.91) (Fig. 2). The heterogeneity found in this analysis is widely explainable in the subgroup analysis of aspirin, clopidogrel, and other P2Y12i users.

Uninterrupted clopidogrel and other P2Y12i were associated with a higher risk of PPB (OR 5.29; CI 2.99-9.379) than uninterrupted aspirin (OR 1.87; CI 1.32-2.65) compared to control (Figs. 3, 4).

\section{Immediate post-polypectomy bleeding}

Three studies (2 full-text and one abstract) [22-24] assessed the immediate PPB risk in patients on uninterrupted P2Y12i therapy. Uninterrupted P2Y12i was associated with an increased risk of PPB compared to control group (OR 4.43; CI 1.40-14.00) although it was higher in clopidogrel users than in the other P2Y12i user group (OR 13.28 and OR 2.59, respectively) (Supplementary Fig. 1).

Two studies evaluated the immediate PPB risk in patients on uninterrupted aspirin therapy. [23, 24] Among uninterrupted aspirin group, there were no significant differences in the number of immediate PPB bleeding events compared to the control group (OR 1.43; CI 0.78-2.64) (Supplementary Fig. 2).

\section{Delayed post-polypectomy bleeding}

Four studies evaluated the delayed PPB risk in patients on uninterrupted APAs. Two studies for P2Y12i (one fulltext and one abstract) [22, 24] and two for aspirin [20,24]. Uninterrupted P2Y12i single therapy was associated with an increased risk of PPB compared to control, while there were no significant differences among uninterrupted aspirin group compared to the control group (OR 10.80; CI 4.63-25.16 and OR 2.50; CI 0.63-9.87, respectively) (Supplementary Figs. 3, 4). 


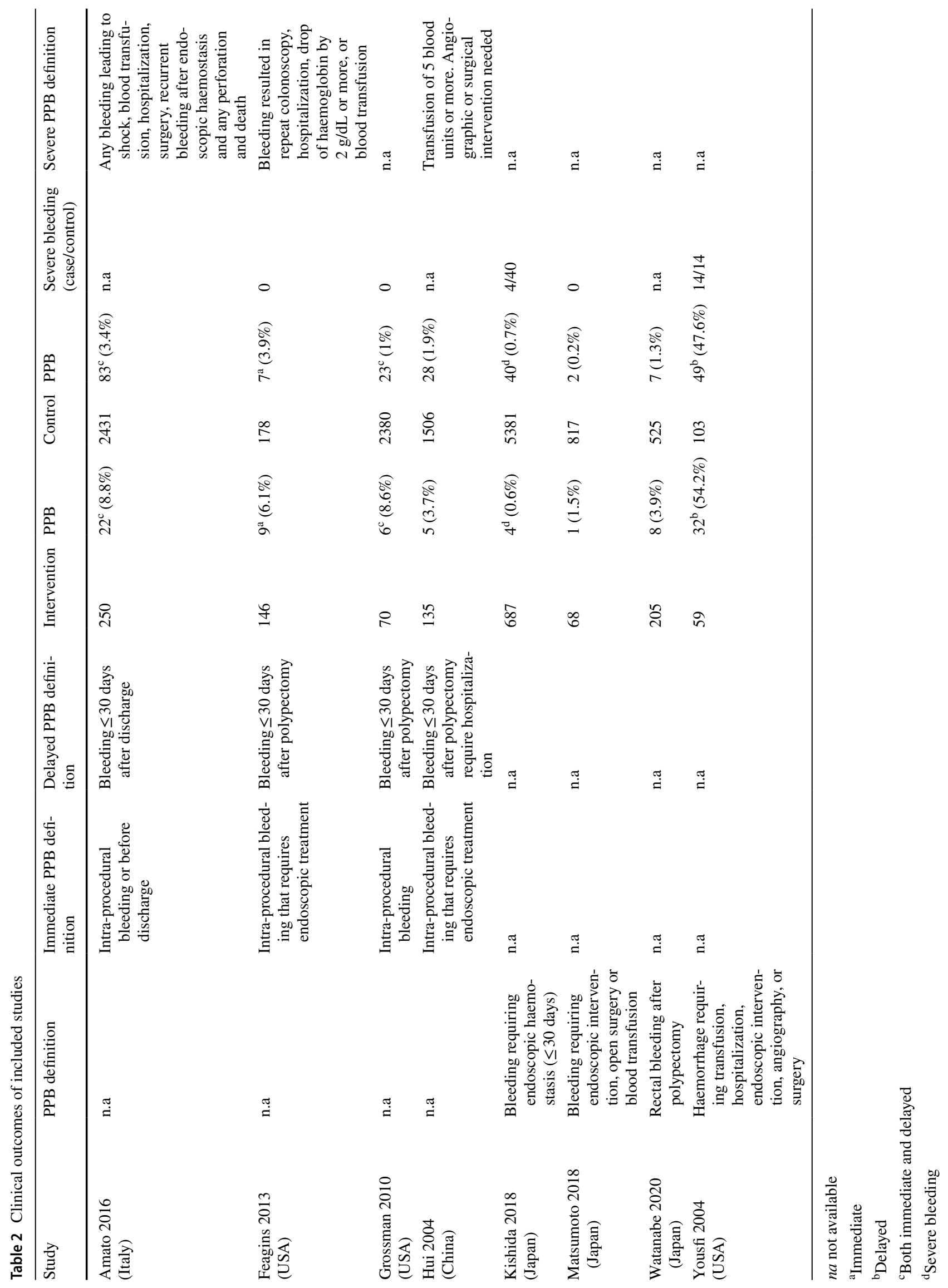


Table 3 GRADE profile

\begin{tabular}{|c|c|c|c|c|c|c|c|c|c|}
\hline \multicolumn{7}{|c|}{ Certainty assessment } & \multicolumn{2}{|c|}{ Summary of findings } & \multirow[t]{2}{*}{ Comments } \\
\hline $\begin{array}{l}\text { Participants } \\
\text { (studies) } \\
\text { Follow-up }\end{array}$ & Risk of bias & $\begin{array}{l}\text { Inconsist- } \\
\text { ency }\end{array}$ & Indirectness & Imprecision & $\begin{array}{l}\text { Publication } \\
\text { bias }\end{array}$ & $\begin{array}{l}\text { Overall } \\
\text { certainty of } \\
\text { evidence }\end{array}$ & $\begin{array}{l}\text { Relative } \\
\text { effect } \\
(95 \% \mathrm{CI})\end{array}$ & $\begin{array}{l}\text { Risk dif- } \\
\text { ference } \\
\text { with PPB } \\
\text { on single } \\
\text { APAs/aspirin } \\
\text { therapy }\end{array}$ & \\
\hline
\end{tabular}

$P P B$ on single antiplatelet therapy

$14,941 \quad$ very serious $^{\mathrm{a}}$ serious $^{\mathrm{b}}$ not serious not serious none
$\begin{aligned} & \text { ( } 8 \text { obser- } \\ & \text { vational } \\ & \text { studies })\end{aligned}$

\section{$\begin{array}{ll}\bigoplus \bigcirc \bigcirc \bigcirc & \text { OR } 2.31 \\ \text { Very low } & \text { (1.37 to }\end{array}$ \\ (1.37 to}

studies)

\section{$P P B$ on $P 2 Y 12 i$ therapy}

$6512 \quad$ very serious $^{\mathrm{a}}$ not serious not serious serious $^{\mathrm{d}}$ none
$\begin{aligned} & (5 \text { obser- } \\ & \text { vational } \\ & \text { studies })\end{aligned}$

\section{$P P B$ on aspirin therapy}

$6313 \quad$ serious $^{\mathrm{c}}$ not serious not serious not serious none
$\begin{aligned} & (6 \text { obser- } \\ & \text { vational }\end{aligned}$
studies $)$

\section{Immediate PPB on P2Y12i therapy}

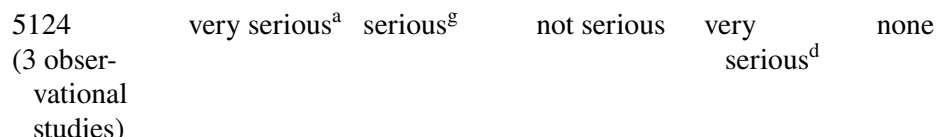

Immediate PPB on aspirin therapy

\begin{tabular}{|c|c|c|c|c|c|c|c|c|c|}
\hline $\begin{array}{l}2940 \\
\text { (2 obser- } \\
\text { vational } \\
\text { studies) }\end{array}$ & serious $^{\mathrm{c}}$ & not serious & not serious & serious $^{\mathrm{f}}$ & none & $\begin{array}{l}\bigoplus \bigoplus \bigcirc \bigcirc \\
\text { Low }\end{array}$ & $\begin{array}{c}\text { OR } 1.43 \\
(0.78 \text { to } \\
2.64)\end{array}$ & $\begin{array}{l}12 \text { more per } \\
1.000 \\
\text { (from } 6 \\
\text { fewer to } 43 \\
\text { more) }\end{array}$ & $\begin{array}{l}\text { The aspirin } \\
\text { may result } \\
\text { in little to } \\
\text { no differ- } \\
\text { ence in } \\
\text { immediate } \\
\text { PPB }\end{array}$ \\
\hline
\end{tabular}

\section{Sensitivity analysis and publication bias}

Sensitivity analysis was conducted excluding the abstract that was the only study with a serious risk of bias. Among the full text, the overall PPB prevalence was higher among patients on
APAs therapy compared to controls with a lower heterogeneity (OR 1.83; CI 1.35-2.49) (Supplementary Fig. 5).

We performed a sensitivity analysis excluding the only study which included only patients with PPB in the case group, with a control group identified among patients matched for 
Table 3 (continued)

\begin{tabular}{|c|c|c|c|c|c|c|c|c|c|}
\hline \multicolumn{7}{|c|}{ Certainty assessment } & \multicolumn{2}{|c|}{ Summary of findings } & \multirow[t]{2}{*}{ Comments } \\
\hline $\begin{array}{l}\text { Participants } \\
\text { (studies) } \\
\text { Follow-up }\end{array}$ & Risk of bias & $\begin{array}{l}\text { Inconsist- } \\
\text { ency }\end{array}$ & Indirectness & Imprecision & $\begin{array}{l}\text { Publication } \\
\text { bias }\end{array}$ & $\begin{array}{l}\text { Overall } \\
\text { certainty of } \\
\text { evidence }\end{array}$ & $\begin{array}{l}\text { Relative } \\
\text { effect } \\
(95 \% \mathrm{CI})\end{array}$ & $\begin{array}{l}\text { Risk dif- } \\
\text { ference } \\
\text { with PPB } \\
\text { on single } \\
\text { APAs/aspirin } \\
\text { therapy }\end{array}$ & \\
\hline \multicolumn{10}{|c|}{ Delayed PPB on P2Y12i therapy } \\
\hline $\begin{array}{l}4919 \\
\text { (2 obser- } \\
\text { vational } \\
\text { studies) }\end{array}$ & very serious ${ }^{\mathrm{a}}$ & not serious & not serious & $\begin{array}{l}\text { very } \\
\text { serious }^{\mathrm{d}}\end{array}$ & none & $\begin{array}{l}\bigoplus \bigcirc \bigcirc \bigcirc \\
\text { Very low }\end{array}$ & $\begin{array}{l}\text { OR } 10.80 \\
(4.63 \text { to } \\
25.16)\end{array}$ & $\begin{array}{l}59 \text { more per } \\
1.000 \\
\text { (from } 23 \text { to } \\
134 \text { more) }\end{array}$ & $\begin{array}{l}\text { The P2Y12i } \\
\text { may } \\
\text { increase } \\
\text { delayed } \\
\text { PPB, } \\
\text { but the } \\
\text { evidence } \\
\text { is very } \\
\text { uncertain }\end{array}$ \\
\hline \multicolumn{10}{|c|}{ Delayed PPB on aspirin therapy } \\
\hline $\begin{array}{l}2805 \\
\text { ( } 2 \text { obser- } \\
\text { vational } \\
\text { studies })\end{array}$ & serious $^{\mathrm{c}}$ & serious $^{\mathrm{e}}$ & not serious & $\begin{array}{l}\text { very } \\
\text { serious }^{\mathrm{d}}\end{array}$ & none & $\underset{\text { Very low }}{\oplus \bigcirc \bigcirc}$ & $\begin{array}{l}\text { OR } 2.50 \\
(0.63 \text { to } \\
9.87)\end{array}$ & $\begin{array}{l}36 \text { more per } \\
1.000 \\
\text { (from } 9 \\
\text { fewer to } \\
181 \text { more) }\end{array}$ & $\begin{array}{l}\text { The aspirin } \\
\text { may } \\
\text { increase } \\
\text { delayed } \\
\text { PPB, } \\
\text { but the } \\
\text { evidence } \\
\text { is very } \\
\text { uncertain }\end{array}$ \\
\hline
\end{tabular}

CI confidence interval, $O R$ odds ratio

${ }^{a}$ A large study (Grossman 2010) have a serious risk of bias in three domains (Bias due to confounding, Bias due to missing data, bias in measurement of outcomes)

${ }^{b}$ Moderate heterogeneity. It is widely explainable considering the different drugs in the intervention group

${ }^{\mathrm{c}}$ All the studies included have at least one domine at moderate risk of bias. No serious or critical risk biases were detected

${ }^{\mathrm{d}}$ Wide confidence intervals and small sample size

${ }^{\mathrm{e}}$ High heterogeneity due to difference in included patients. Yousfi 2004 included only patients with PPB in the case group, with a control group identified among patients matched for age, gender, and cardiovascular morbidity

${ }^{\mathrm{f}}$ Very small sample size

${ }^{\mathrm{g}}$ Moderate heterogeneity due to a large single abstract

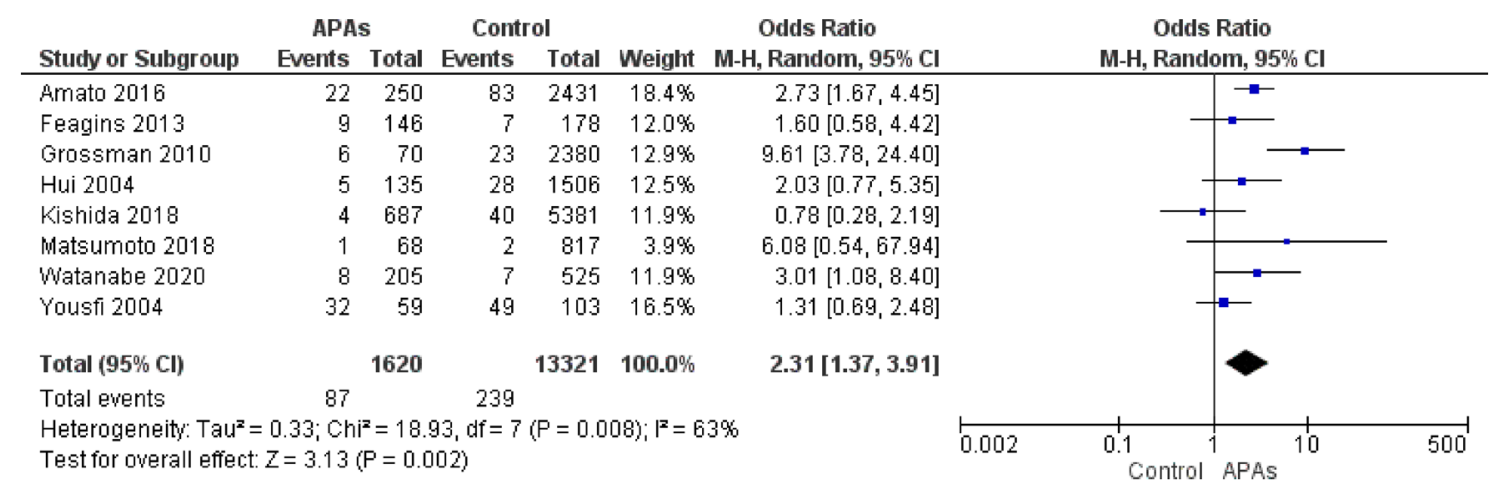

Fig. 2 Overall PPB in APAs single therapy 


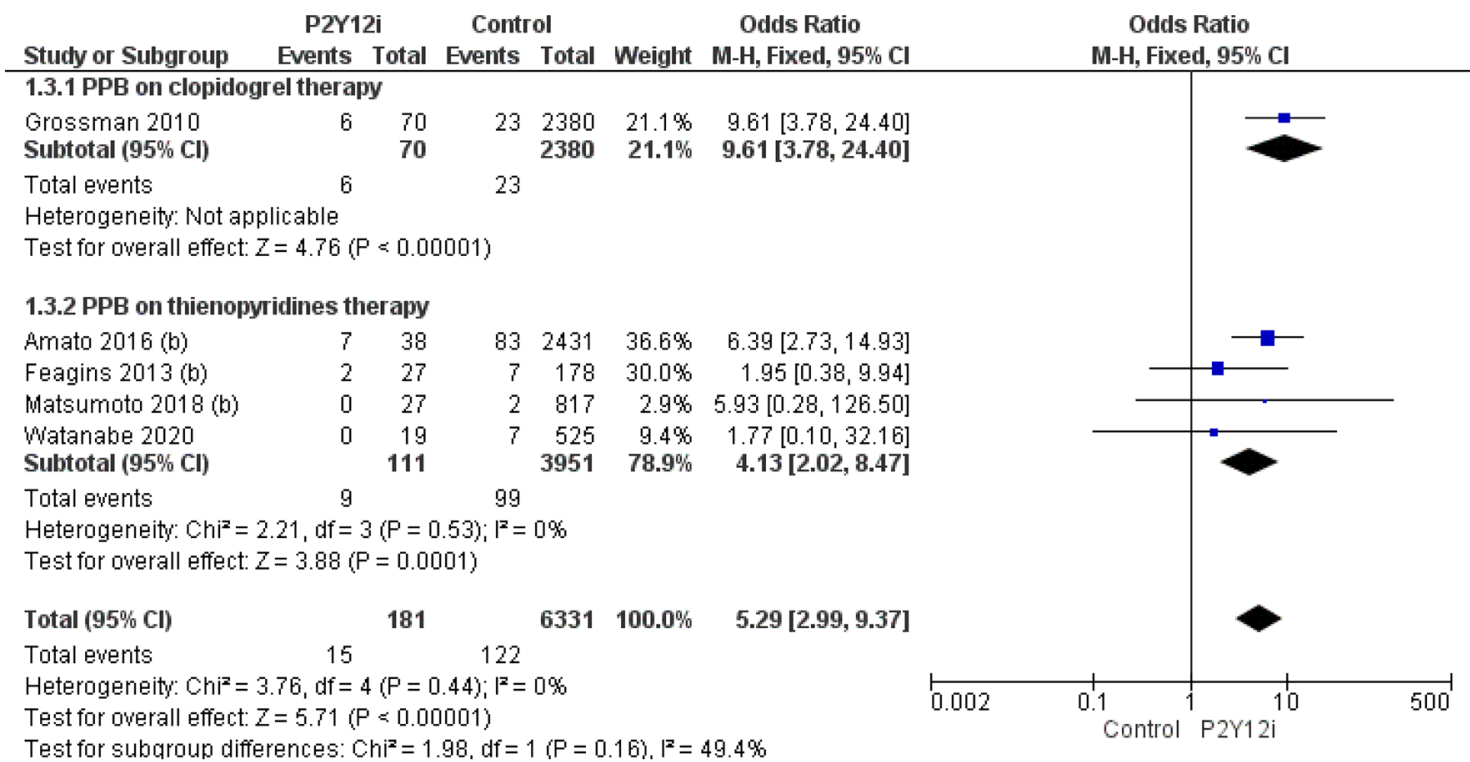

Fig. 3 Overall PPB in P2Y12i single therapy

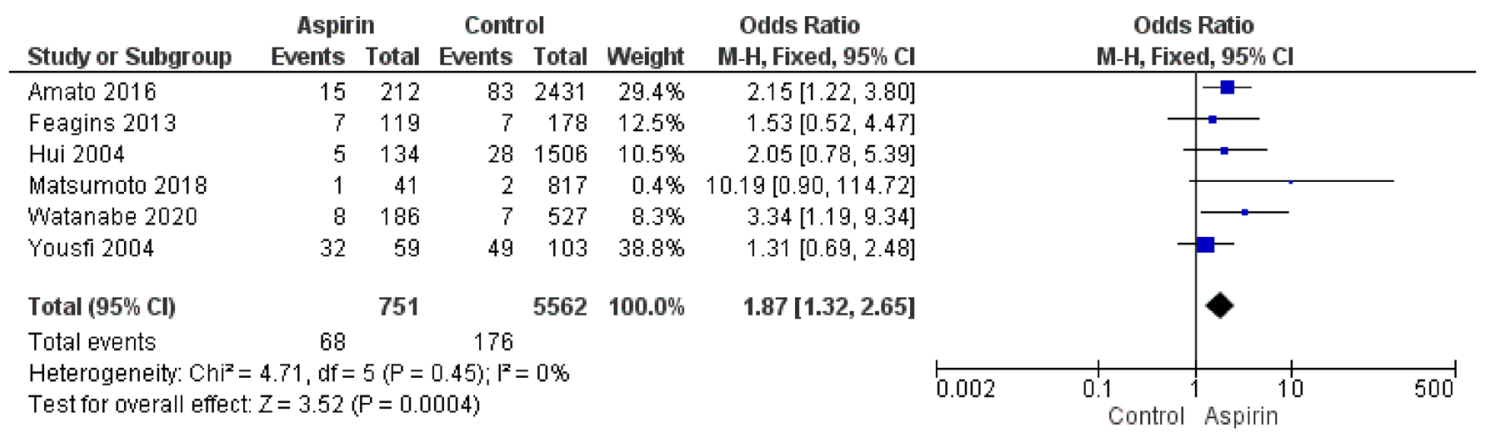

Fig. 4 Overall PPB in aspirin single therapy

age, gender, and cardiovascular morbidity. In this study, the prevalence of PPB was 50\% [20]. The pooled OR of PPB in APAs users was 2.59 (CI 1.45-4.63) (Supplementary Fig. 6).

The funnel plot and the Egger's regression test for publication bias weren't performed because only 8 studies were included.

\section{Discussion}

The results of our meta-analysis showed that patients on single antiplatelet therapy such as P2Y12i or aspirin had a 2.31-fold higher risk of bleeding compared to control (CI 1.37-3.91).
This risk appeared higher among patients on clopidogrel therapy. It is important to underline that, only an abstract assessed the risk of PPB among patients on clopidogrel.

Among patients on aspirin single therapy, the overall PPB risk was 2.04-fold higher (CI 1.48-2.80), although there was no difference in both immediate (OR 1.43; CI 0.78-2.64) and delayed PPB (OR 2.50; CI 0.63-9.87) compared to the control group. It is important to underline that these data were available only in two studies. Therefore, both these subgroup analyses involved a suboptimal sample size.

Moreover, patients on P2Y12i single therapy had a higher risk of both immediate and delayed PPB (immediate OR 4.43; CI 1.40-14.00; delayed OR 10.80; CI 4.63-25.16). 
The data concerning the size of lesions, localization, and resection techniques in patients on APAs were not extractable in relation to the outcomes of our meta-analysis. On the other hand, the great majority of polyps evaluated in the included studies were $<10 \mathrm{~mm}$; therefore, based on the above data, our result is less easily generalizable for polyps $>10 \mathrm{~mm}$. Among the overall population of the studies included: 13,841 patients underwent hot snare polypectomy, 5882 patients underwent cold forceps polypectomy, 3332 patients underwent cold snare polypectomy, 746 patients underwent hot biopsy polypectomy; in three studies some techniques were counted in pairs, 532 patients underwent hot + cold snare polypectomy, 3057 patients underwent cold snare + cold forceps polypectomy. Moreover, 19,635 patients that underwent polypectomy had polyps $<10 \mathrm{~mm}$ and 4206 patients that underwent polypectomy had polyps $>10 \mathrm{~mm}$. Data concerning which drug the patients were taking related to the technique or the size of the polyps were not extractable, making it impossible to compare these data and obtain the outcome of interest.

Our meta-analysis has some limitations. First, we included only observational studies because RCTs assessing the PPB risk among patients on single antiplatelet therapy are not currently available.

Second, only one abstract assessed the PPB risk (both delayed and immediate) among patients on clopidogrel, and not any performed a sub-analysis among the other P2Y12i. Furthermore, PPB among patients in single antiplatelet therapy was the main outcome in only two included studies [20, 22].

A recent RCT, published by Chan and colleagues, evaluated the risk of PPB with uninterrupted clopidogrel therapy vs placebo, taken until the day of colonoscopy. The results showed that a slightly larger proportion of patients continuing clopidogrel developed delayed (3.8\% vs 3.6\%) and immediate ( $8.5 \%$ vs $5.5 \%$ ) post-polypectomy bleeding, although this difference was not statistically significant [28]. However, only $7.7 \%$ of the polyps included in this $\mathrm{RCT}$, were $\geq 10 \mathrm{~mm}$ in size, so the RCT is strongly underpowered for this subgroup analysis, and the generalizability of the conclusion for polyps $>10 \mathrm{~mm}$ is limited [29, 30]. Moreover, about $80 \%$ of patients were on DAPT and these data are hardly generalizable to a group of patients who are not on dual antiplatelet therapy. It is important to underline that PPB is rarely life threatening, whereas a thrombotic event caused by clopidogrel interruption can be harmful. Therefore, any discussion about the reduction in the risk of PPB is of secondary importance compared to cardiovascular thrombotic events caused by interruption of antiplatelet therapy $[29,30]$.

Few meta-analyses evaluated the colonoscopic postpolypectomy bleeding in patients on antiplatelet therapy [31-34]. However, none of these assessed the risk of PPB in single APAs. Two of these meta-analyses evaluated the PPB risk in patients exposed to both aspirin and NSAIDs $[31,33]$. Moreover, Pigò et al. included patients who underwent colorectal polypectomy with snare, ESD, or EMR. Colorectal ESD on APAs, except for aspirin alone, were independent risk factors for delayed bleeding (OR 4.04; CI 1.44-11.30) [3, 35]. ASGE guidelines recommend discontinuation of thienopyridines at least 5 to 7 days before high-risk endoscopic procedure or switching to aspirin monotherapy which may be continued safely in the peri-endoscopic period [4]. Two well-conducted metaanalyses assessed the pooled relative risk ratio of colonoscopic PPB in patients who continued clopidogrel therapy; however, they both included patients on an uninterrupted single APAs therapy or DAPT $[32,34]$.

On the other hand, although patients on APAs therapy have an established increased risk of PPB, aspirin nonadherence or withdrawal is associated with a three-fold higher risk of major adverse cardiovascular events (OR $3.14 ; 1.75-5.61)$ [11]. A U.S. observational study including 2197 cases of ischemic stroke identified through hospital discharge records, reported that $5.2 \%$ of strokes occurred within 60 days of an antithrombotic medication withdrawal [36]. Therefore, it is essential to balance the PPB risk of endoscopic polypectomy and the risk of major adverse cardiovascular events due to discontinuation of therapy.

In our meta-analysis, we analysed only patients in single antiplatelet therapy. These inclusion criteria are crucial for the APAs management before the colonoscopy with polypectomy. It is important to underline that patients on DAPT should suspend P2Y12i agents 7 days before the endoscopy and continue aspirin if they have low thrombotic risk, and liaise with a cardiologist about the risk/benefit of discontinuing P2Y12i in patients at high thrombotic risk [3].

Our result showed a moderate increase of PPB in patients with uninterrupted antiplatelet therapy. Although a moderate heterogeneity in our main outcome, these data appeared solid and the heterogeneity is widely explainable with the different PPB risk observed for the various antiplatelet agents, as shown in the subgroup analysis. Moreover, after the exclusion of the abstract (with a serious risk of bias) the pooled PPB risk in patients with uninterrupted antiplatelet agents remained higher compared to the control group, despite the slightest heterogeneity (OR 1.51; CI 1.03-2.22).

It is important to underline that no death was observed in all the studies included.

The risk of major adverse cardiovascular events in patients who discontinue aspirin single therapy is greater than the risk of delayed PPB in patients who continue this treatment. 
Despite this, a U.S. survey showed that less than half of the endoscopy units routinely continue aspirin before colonoscopies [37]. Another German survey, regarding the interruption of clopidogrel and/or dual antiplatelet therapy, demonstrated that in this setting the decision has an individual basis because the current guidelines on endoscopic procedures in patients under clopidogrel/dual antiplatelet therapy are mainly based on expert opinion and supported by only weak evidence [38].

One of the possible causes of the scarcity of these data is given by the few therapeutic indications present in the current cardiological guidelines about P2Y12i single therapy $[39,40]$.

It is extremely important to produce more evidence and strongest data about PPB in patients on uninterrupted single antiplatelet therapy. In particular, there is a lack of RCTs assessing the increase in the risk of PPB among patients on single APAs therapy compared with patients who withdrawal the antiplatelet therapy. This setting would reflect the scenario for the management of APAs therapy in which the clinical decision is made.

In conclusion, uninterrupted single antiplatelet therapy may increase the risk of PPB, but the evidence is very uncertain.

Concerning P2Y12i, the guidelines suggest that the temporary interruption of this therapy should be carefully evaluated, considering the potential higher risk of major adverse cardiovascular events; however, P2Y12i may increase the risk of PPB, but the evidence is very uncertain.

Uninterrupted single aspirin therapy probably results in a slight increase of PPB when compared with control.

It is important to underline that, aspirin withdrawal results in high risk of major adverse cardiovascular events, thus it should be continued before the colonoscopic polypectomy.

Therefore, both the risk of endoscopic post-polypectomy bleeding and the risk of major adverse cardiovascular events should be assessed on a case-by-case basis, assessing both the degree of thrombotic risk and the degree of bleeding risk in the individual patient with the discontinuation of single antiplatelet therapy. However, to produce more clear and solid clinical evidence, RCTs including patients on single APAs therapy compared with patients who withdraw the antiplatelet therapy are needed.

Supplementary Information The online version contains supplementary material available at https://doi.org/10.1007/s00464-021-08975-0.

Acknowledgements We thank Kazuhiro Watanabe and Naoyoshi Nagata for responding to our queries about their papers and providing us with extra data.
Author contributions MV and GL: study concept and design and drafting of the manuscript; MV, MM, SF and AM: acquisition, analysis, and interpretation of data; SL, GS, FV, AV and SR: interpretation of data and critical revision of the manuscript. All authors approved the final draft submitted. All authors approved the final draft submitted. Each one of the authors was involved in the writing and revision of the manuscript.

Funding None.

\section{Declarations}

Disclosures Marco Valvano, Stefano Fabiani, Marco Magistroni, Antonio Mancusi, Salvatore Longo, Gianpiero Stefanelli, Filippo Vernia, Angelo Viscido, Silvio Romano and Giovanni Latella have no conflicts of interest or financial ties to disclose.

Open Access This article is licensed under a Creative Commons Attribution 4.0 International License, which permits use, sharing, adaptation, distribution and reproduction in any medium or format, as long as you give appropriate credit to the original author(s) and the source, provide a link to the Creative Commons licence, and indicate if changes were made. The images or other third party material in this article are included in the article's Creative Commons licence, unless indicated otherwise in a credit line to the material. If material is not included in the article's Creative Commons licence and your intended use is not permitted by statutory regulation or exceeds the permitted use, you will need to obtain permission directly from the copyright holder. To view a copy of this licence, visit http://creativecommons.org/licenses/by/4.0/.

\section{References}

1. Kim SY, Kim HS, Park HJ (2019) Adverse events related to colonoscopy: Global trends and future challenges. World J Gastroenterol 25:190-204

2. Reumkens A, Rondagh EJA, Bakker CM, Winkens B, Masclee AAM, Sanduleanu S (2016) Post-colonoscopy complications: a systematic review, time trends, and meta-analysis of populationbased studies. Am J Gastroenterol 111:1092-1101

3. Veitch AM, Radaelli F, Alikhan R, Dumonceau J-M, Eaton D, Jerrome J, Lester W, Nylander D, Thoufeeq M, Vanbiervliet G, Wilkinson JR, van Hooft JE (2021) Endoscopy in patients on antiplatelet or anticoagulant therapy: British Society of Gastroenterology (BSG) and European Society of Gastrointestinal Endoscopy (ESGE) guideline update. Endoscopy 53:947-969

4. Acosta RD, Abraham NS, Chandrasekhara V, Chathadi KV, Early DS, Eloubeidi MA, Evans JA, Faulx AL, Fisher DA, Fonkalsrud L, Hwang JH, Khashab MA, Lightdale JR, Muthusamy VR, Pasha SF, Saltzman JR, Shaukat A, Shergill AK, Wang A, Cash BD, DeWitt JM (2016) The management of antithrombotic agents for patients undergoing GI endoscopy. Gastrointest Endosc 83:3-16

5. Grossberg LB, Papamichael K, Leffler DA, Sawhney MS, Feuerstein JD (2020) Patients over age 75 are at increased risk of emergency department visit and hospitalization following colonoscopy. Dig Dis Sci 65:1964-1970

6. Heitman SJ, Ronksley PE, Hilsden RJ, Manns BJ, Rostom A, Hemmelgarn BR (2009) Prevalence of adenomas and colorectal cancer in average risk individuals: a systematic review and metaanalysis. Clin Gastroenterol Hepatol 7:1272-1278

7. O'Brien CW, Juraschek SP, Wee CC (2019) Prevalence of aspirin use for primary prevention of cardiovascular disease in the United 
States: results from the 2017 National Health Interview Survey. Ann Intern Med 171:596-598

8. Milling TJ Jr, Ziebell CM (2020) A review of oral anticoagulants, old and new, in major bleeding and the need for urgent surgery. Trends Cardiovasc Med 30:86-90

9. Bouget J, Balusson F, Viglino D, Roy PM, Lacut K, Pavageau L, Oger E (2020) Major bleeding risk and mortality associated with antiplatelet drugs in real-world clinical practice. A prospective cohort study. PLoS ONE 15:1-18

10. Feagins LA (2017) Management of anticoagulants and antiplatelet agents during colonoscopy. Am J Med 130:786-795

11. Biondi-Zoccai GGL, Lotrionte M, Agostoni P, Abbate A, Fusaro M, Burzotta F, Testa L, Sheiban I, Sangiorgi G (2006) A systematic review and meta-analysis on the hazards of discontinuing or not adhering to aspirin among 50279 patients at risk for coronary artery disease. Eur Heart J 27:2667-2674

12. Moher D, Liberati A, Tetzlaff J, Altman DG, Altman D, Antes G, Atkins D, Barbour V, Barrowman N, Berlin JA, Clark J, Clarke M, Cook D, D’Amico R, Deeks JJ, Devereaux PJ, Dickersin K, Egger M, Ernst E, Gøtzsche PC, Grimshaw J, Guyatt G, Higgins J, Ioannidis JPA, Kleijnen J, Lang T, Magrini N, McNamee D, Moja L, Mulrow C, Napoli M, Oxman A, Pham B, Rennie D, Sampson M, Schulz KF, Shekelle PG, Tovey D, Tugwell P (2009) Preferred reporting items for systematic reviews and meta-analyses: the PRISMA statement. PLoS Med 6:7

13. Sterne JAC, Hernán MA, Reeves BC, Savović J, Berkman ND, Viswanathan M, Henry D, Altman DG, Ansari MT, Boutron I, Carpenter JR, Chan AW, Churchill R, Deeks JJ, Hróbjartsson A, Kirkham J, Jüni P, Loke YK, Pigott TD, Ramsay CR, Regidor D, Rothstein HR, Sandhu L, Santaguida PL, Schünemann HJ, Shea B, Shrier I, Tugwell P, Turner L, Valentine JC, Waddington H, Waters E, Wells GA, Whiting PF, Higgins JPT (2016) Risk Of Bias In Non-randomized Studies of Interventions (ROBINS-I): detailed guidance. BMJ 355:i4919. https:// doi.org/10.1136/bmj.i4919

14. Guyatt G, Oxman AD, Akl EA, Kunz R, Vist G, Brozek J, Norris S, Falck-Ytter Y, Glasziou P, Debeer H, Jaeschke R, Rind D, Meerpohl J, Dahm P, Schünemann HJ (2011) GRADE guidelines: 1. Introduction-GRADE evidence profiles and summary of findings tables. J Clin Epidemiol 64:383-394

15. Guyatt GH, Oxman AD, Kunz R, Atkins D, Brozek J, Vist G, Alderson P, Glasziou P, Falck-Ytter Y, Schünemann HJ (2011) GRADE guidelines: 2. Framing the question and deciding on important outcomes. J Clin Epidemiol 64:395-400

16. Santesso N, Glenton C, Dahm P, Garner P, Akl EA, Alper B, Brignardello-Petersen R, Carrasco-Labra A, De Beer H, Hultcrantz M, Kuijpers T, Meerpohl J, Morgan R, Mustafa R, Skoetz N, Sultan S, Wiysonge C, Guyatt G, Schünemann HJ (2020) GRADE guidelines 26: informative statements to communicate the findings of systematic reviews of interventions. J Clin Epidemiol 119:126-135

17. Higgins JPT, Thomas J, Chandler J, Cumpston M, Li T, Page MJ, Welch VA (2019) Cochrane handbook for systematic reviews of interventions, 2nd edn. Wiley, Chichester

18. Egger M, Smith GD, Schneider M, Minder C (1997) Bias in meta-analysis detected by a simple, graphical test. Br Med J 315:629-634

19. Guyatt GH, Oxman AD, Vist GE, Kunz R, Falck-Ytter Y, Alonso-Coello P, Schünemann HJ (2009) GRADE: an emerging consensus on rating quality of evidence and strength of recommendations. Chin J Evid-Based Med 9:8-11

20. Yousfi M, Gostout CJ, Baron TH, Hernandez JL, Keate R, Fleischer DE, Sorbi D (2004) Postpolypectomy lower gastrointestinal bleeding: potential role of aspirin. Am J Gastroenterol 99:1785-1789
21. Hui AJ, Wong RMY, Ching JYL, Hung LCT, Chung SCS, Sung JJY (2004) Risk of colonoscopic polypectomy bleeding with anticoagulants and antiplatelet agents: analysis of 1657 cases. Gastrointest Endosc 59:44-48

22. Grossman E, Maranino A, Zamora D et al (2010) Antiplatelet medications increase the risk of post-polypectomy bleeding. Am J Gastroenterol 105:S391-S392

23. Feagins LA, Iqbal R, Harford WV, Halai A, Cryer BL, Dunbar KB, Davila RE, Spechler SJ (2013) Low rate of postpolypectomy bleeding among patients who continue thienopyridine therapy during colonoscopy. Clin Gastroenterol Hepatol Off Clin Pract J Am Gastroenterol Assoc 11:1325-1332

24. Amato A, Radaelli F, Dinelli M, Crosta C, Cengia G, Beretta P, Devani M, Lochis D, Manes G, Fini L, Paggi S, Passoni GR, Repici A, Redaelli A, Cestari R, Prada A, Bernasconi G, Pallotta S, Gebbia C, Cambareri A, Rovedatti L, Perego M, Viganò C, Zappa MA, Bargiggia S, Parente F, Spinzi G, Leoci C, Piubello W, Grillo S (2016) Early and delayed complications of polypectomy in a community setting: the SPoC prospective multicentre trial. Dig Liver Dis 48:43-48

25. Matsumoto M, Yoshii S, Shigesawa T, Dazai M, Onodera M, Kato M, Sakamoto N (2018) Safety of cold polypectomy for colorectal polyps in patients on antithrombotic medication. Digestion 97:76-81

26. Kishida Y, Hotta K, Imai K, Ito S, Yoshida M, Kawata N, Tanaka M, Kakushima N, Takizawa K, Ishiwatari H, Matsubayashi H, Ono H (2019) Risk analysis of colorectal post-polypectomy bleeding due to antithrombotic agent. Digestion 99:148-156

27. Watanabe K, Nagata N, Yanagisawa N, Shimbo T, Okubo H, Imbe K, Yokoi C, Yanase M, Kimura A, Akiyama J, Uemura N (2020) Effect of antiplatelet agent number, types, and preendoscopic management on post-polypectomy bleeding: validation of endoscopy guidelines. Surg Endosc 35(1):317-325

28. Chan FKL, Kyaw MH, Hsiang JC, Suen BY, Kee KM, Tse YK, Ching JYL, Cheong PK, Ng D, Lam K, Lo A, Lee V, Ng SC (2019) Risk of postpolypectomy bleeding with uninterrupted clopidogrel therapy in an industry-independent, double-blind, randomized trial. Gastroenterology 156:918-925

29. Radaelli F, Mogavero G, Paggi S (2019) RE: risk of postpolypectomy bleeding with uninterrupted clopidogrel therapy in an industry-independent, double-blind, randomized. Trial Gastroenterol 157:579

30. Sonneveld MJ, Honkoop P, ter Borg PCJ (2019) A randomized trial of interrupted clopidogrel in patients undergoing polypectomy: more questions than answers? Gastroenterology 157:580-581

31. Pigò F, Bertani H, Grande G, Federica A, Vavassori S, Conigliaro RL (2018) Post-polypectomy bleeding after colonoscopy on uninterrupted aspirin/non steroideal antiflammatory drugs: systematic review and meta-analysis. Dig Liver Dis 50:20-26

32. Gandhi S, Narula N, Mosleh W, Marshall JK, Farkouh M (2013) Meta-analysis: colonoscopic post-polypectomy bleeding in patients on continued clopidogrel therapy. Aliment Pharmacol Ther 37:947-952

33. Shalman D, Gerson LB (2015) Systematic review with metaanalysis: the risk of gastrointestinal haemorrhage post-polypectomy in patients receiving anti-platelet, anti-coagulant and/or thienopyridine medications. Aliment Pharmacol Ther 42:949-956

34. Li D, Chang X, Fang X, Wang J, Yu Z, Wei C, Xiong F, Xu Z, Zhang D, Liu T, Luo M, Wang L, Yao J (2020) Colonoscopic post-polypectomy bleeding in patients on uninterruptedclopidogrel therapy: a systematic review and meta-analysis. Exp Ther Med 2:3211-3218. https://doi.org/10.3892/etm.2020.8597

35. Seo M, Song EM, Cho JW, Lee YJ, Lee BI, Kim JS, Jeon SW, Jang HJ, Yang DH, Ye BD, Byeon JS (2019) A risk-scoring 
model for the prediction of delayed bleeding after colorectal endoscopic submucosal dissection. Gastrointest Endosc 89:990-998

36. Broderick JP, Bonomo JB, Kissela BM, Khoury JC, Moomaw CJ, Alwell K, Woo D, Flaherty ML, Khatri P, Adeoye O, Ferioli S, Kleindorfer DO (2011) Withdrawal of antithrombotic agents and its impact on ischemic stroke occurrence. Stroke 42:2509-2514

37. Robbins R, Tian C, Singal A, Agrawal D (2015) Periprocedural management of aspirin during colonoscopy: a survey of practice patterns in the United States. Gastrointest Endosc 82:895-900

38. Abdel Samie A, Theilmann L, Labenz J (2014) Endoscopic procedures in patients under clopidogrel or dual antiplatelet therapy: a survey among German gastroenterologists and current guidelines. Z Gastroenterol 52:425-428

39. Ibanez B, James S, Agewall S, Antunes MJ, Bucciarelli-Ducci C, Bueno H, Caforio ALP, Crea F, Goudevenos JA, Halvorsen S, Hindricks G, Kastrati A, Lenzen MJ, Prescott E, Roffi M, Valgimigli M, Varenhorst C, Vranckx P, Widimský P, Baumbach A, Bugiardini R, Coman IM, Delgado V, Fitzsimons D, Gaemperli O, Gershlick AH, Gielen S, Harjola VP, Katus HA, Knuuti J, Kolh P, Leclercq C, Lip GYH, Morais J, Neskovic AN, Neumann FJ, Niessner A, Piepoli MF, Richter DJ, Shlyakhto E, Simpson IA, Steg PG, Terkelsen CJ, Thygesen K, Windecker S, Zamorano JL, Zeymer U, Chettibi M, Hayrapetyan HG, Metzler B, Ibrahimov F, Sujayeva V, Beauloye C, Dizdarevic-Hudic L, Karamfiloff K, Skoric B, Antoniades L, Tousek P, Terkelsen CJ, Shaheen SM, Marandi T, Niemela M, Kedev S, Gilard M, Aladashvili A, Elsaesser A, Kanakakis IG, Merkely B, Gudnason T, Iakobishvili Z, Bolognese L, Berkinbayev S, Bajraktari G, Beishenkulov M, Zake I, Lamin H Ben, Gustiene O, Pereira B, Xuereb RG, Ztot S, Julieb $\varnothing$ V, Legutko J, Timoteo AT, Tatu-Chit soiu G, Yakovlev A, Bertelli L, Nedeljkovic M, Studencan M, Bunc M, de Castro AMG, Petursson P, Jeger R, Mourali MS, Yildirir A, Parkhomenko A, Gale CP (2018) 2017 ESC Guidelines for the management of acute myocardial infarction in patients presenting with ST-segment elevation. Eur Heart J 39:119-177

40. Collet J-P, Thiele H, Barbato E, Barthélémy O, Bauersachs J, Bhatt DL, Dendale P, Dorobantu M, Edvardsen T, Folliguet T,
Gale CP, Gilard M, Jobs A, Jüni P, Lambrinou E, Lewis BS, Mehilli J, Meliga E, Merkely B, Mueller C, Roffi M, Rutten FH, Sibbing D, Siontis GCM, Kastrati A, Mamas MA, Aboyans V, Angiolillo DJ, Bueno H, Bugiardini R, Byrne RA, Castelletti S, Chieffo A, Cornelissen V, Crea F, Delgado V, Drexel H, Gierlotka M, Halvorsen S, Haugaa KH, Jankowska EA, Katus HA, Kinnaird T, Kluin J, Kunadian V, Landmesser U, Leclercq C, Lettino M, Meinila L, Mylotte D, Ndrepepa G, Omerovic E, Pedretti RFE, Petersen SE, Petronio AS, Pontone G, Popescu BA, Potpara T, Ray KK, Luciano F, Richter DJ, Shlyakhto E, Simpson IA, SousaUva M, Storey RF, Touyz RM, Valgimigli M, Vranckx P, Yeh RW, Barbato E, Barthélémy O, Bauersachs J, Bhatt DL, Dendale P, Dorobantu M, Edvardsen T, Folliguet T, Gale CP, Gilard M, Jobs A, Jüni P, Lambrinou E, Lewis BS, Mehilli J, Meliga E, Merkely B, Mueller C, Roffi M, Rutten FH, Sibbing D, Siontis GCM, Kastrati A, Mamas MA, Aboyans V, Angiolillo DJ, Bueno H, Bugiardini R, Byrne RA, Castelletti S, Chieffo A, Cornelissen V, Crea F, Delgado V, Drexel H, Gierlotka M, Halvorsen S, Haugaa KH, Jankowska EA, Katus HA, Kinnaird T, Kluin J, Kunadian V, Landmesser U, Leclercq C, Lettino M, Meinila L, Mylotte D, Ndrepepa G, Omerovic E, Pedretti RFE, Petersen SE, Petronio AS, Pontone G, Popescu BA, Potpara T, Ray KK, Luciano F, Richter DJ, Shlyakhto E, Simpson IA, Sousa-Uva M, Storey RF, Touyz RM, Valgimigli M, Vranckx P, Yeh RW, Barbato E, Barthélémy O, Bauersachs J, Bhatt DL, Dendale P, Dorobantu M, Edvardsen T, Folliguet T, Gale CP, Gilard M, Jobs A, Jüni P, Lambrinou E, Lewis BS, Mehilli J, Meliga E, Merkely B, Mueller C, Roffi M, Rutten FH, Sibbing D, Siontis GCM (2020) 2020 ESC Guidelines for the management of acute coronary syndromes in patients presenting without persistent ST-segment elevation. Eur Heart J 1-79.

Publisher's Note Springer Nature remains neutral with regard to jurisdictional claims in published maps and institutional affiliations. 